Jurnal Keperawatan Silampari

Volume 2, Nomor 2, Juni 2019

e-ISSN: 2581-1975

p-ISSN: 2597-7482

DOI: https://doi.org/10.31539/jks.v2i2.533

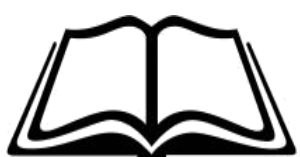

IDMEKpe

\title{
EFEKTIVITAS EXERCISE INTRADIALISIS MENGGUNAKAN BARBELL DAN RANGE OF MOTION (ROM) TERHADAP ADEKUASI HEMODIALISA PADA PASIEN PENYAKIT GINJAL KRONIK
}

\author{
Yestiani Norita Joni ${ }^{1}$, Busjra M. Nur ${ }^{2}$, Fitrian Rayasari ${ }^{3}$ \\ Program Studi Ners, STIKES Kesetiakawanan Sosial Indonesia ${ }^{1}$ \\ Program Studi Magister Keperawatan, Universitas Muhammadiyah Jakarta ${ }^{2,3}$ \\ etinjoni784@gmail.com ${ }^{1}$
}

\begin{abstract}
ABSTRAK
Tujuan penelitian ini adalah diketahui efektifitas exercise intradialisis menggunakan barbell dan Range Of Motion (ROM) terhadap adekuasi hemodialisa pada pasien penyakit ginjal kronik di ruang hemodialisa RSIJ Sukapura tahun 2018. Rancangan penelitian ini menggunakan desain dengan non probalitas pre dan post test two groups without control design. Hasil perbedaan efektifitas nilai adekuasi antara kedua kelompok intervensi sesudah diberikan intervensi adalah pada intervensi barbell diperoleh1,33 dengan standar deviasi 0,485, standar eror 0,114. Sedangkan pada kelompok intervensi ROM 1,67 standar deviasi 0,485, standar eror 0,114 dan niilai $p$ value $0,047(>0,05)$. Simpulan, tidak ada perbedaan nilai yang bermakna pada adekuasi hemodialisa antara kelompok intervensi barbell ROM sesudah intervensi.
\end{abstract}

Kata Kunci: Adekuasi Hemodialisa, Barbell, Efektifitas Exercise, Intradialisis, Range Of Motion (ROM)

\begin{abstract}
The purpose of this study is to know the effectiveness of intradialysis exercise using barbells and Range of Motion (ROM) on the adequacy of hemodialysis in patients with chronic kidney disease in the hemodialysis room of RSIJ Sukapura in 2018. The design of this study uses a design with non-probability pre and post test two groups without control design. The result of the difference in the effectiveness of the adequacy values between the two intervention groups after the intervention was given was the barbell intervention obtained 1,33 with a standard deviation of 0.485 , an error standard of 0.114 . Whereas in the ROM intervention group 1.67 the standard deviation was 0.485 , the standard error was 0.114 and the p-value was 0.047 (>0.05). Conclusion, there was no significant difference in the value of hemodialysis adequacy between the barbellROM intervention groups after the intervention.
\end{abstract}

Keywords: Hemodialysis Adequacy, Barbell, Exercise Effectiveness, Intradialysis, Range Of Motion (ROM) 


\section{PENDAHULUAN}

Penyakit ginjal kronik adalah istilah umum yang menggambarkan kerusakan ginjal atau penurunan laju filtrasi glomelurus (LFG) yang berlangsung selama 3 bulan atau lebih. Penyakit ginjal kronik diasosiasikan dengan kualitas hidup, peningkatan perawatan kesehatan dan kematian dini (Brunner, Suddarth's, 2014).

Menurut data dari United State Renal Data System (USRDS) tahun 2013 di Amerika Serikat Prevalensi penyakit ginjal kronik meningkat sebesar 20\% - 30\% setiap tahunnyasejaktahun 2010. Menurut Data Badan Kesehatan Dunia atau World Health Organization (WHO) menyatakan jumlah penderita ginjal baik akut maupun kronik yang mendapatkan pengobatan sebanyak 25\% dan12,5\% yang terobati dengan baik (USRDS, 2013).

Menurut data dari Yayasan Ginjal Diatrash Indonesia (YGDI) jumlah pasien penderita penyakit ginjal kronik pada saat ini diperkirakan sebanyak 60.000 orang dengan pertambahan 4.400 jiwa setiap tahunnya. Berdasarkan data yang diperoleh dari Yayasan Ginjal Indonesia (YAGINA) pada tahun 2013 terdapat 6,7\% dari penduduk Indonesia sudah mempunyai gangguan fungsi ginjal dengan tingkatan sedang sampai dengan berat. Menurut pusat data dari informasi Perhimpunan Rumah Sakit seluruh Indonesia (PDPERSI) menyatakan jumlah penderita penyakit ginjal kronik diperkirakan pada tahun 2025 mendatangakan mencapai sebanyak247.500 kasus (Yayasan Ginjal Diatrash Indonesia, 2013).

Menurut data data badan kesehatan dunia atau World Health Organization (WHO) tahun 2012 dalam Roesli 2013 meyatakan terdapat penduduk dunia lebih dari 500 juta jiwa yang mengalami penyakit ginjal kronik dan sekitar 1,5 juta jiwa penduduk yang menjalani terapi hemodialisa sepanjang hidupnya. Prevalensi penyakit ginjal kronik berdasarkan data mortality WHO south east asia region pada tahun 2010 - 2012 terdapat sebanyak 250.217 jiwa yang menjalani terapi hemodialisa. Sedikitnya pasien ginjal kronik yang menjalani hemodialisa dipengaruhi oleh beberapa faktor diantaranya selain karena biayanya yang mahal, terapi hemodialisa hanya bisa dilakukan di rumah sakit atau klinik khusus hemodialisa, selain itu unit hemodialisa hanya ada di rumah sakit tertentu saja.

Menurut data Indonesian Renal Registry (IRR) tahun 2013 yang merupakan suatu kegiatan registrasi dari perhimpunan nefrologi Indonesia menyebutkan bahwa di Indonesia menunjukkan terjadinya peningkatan insidensi penderita penyakit ginjal kronik yang menjalani terapi hemodialisa dari tahun 2007-2012 yaitu terdapat sebanyak 6862 penderita pada tahun 2007, dan meningkat berkali lipat sebanyak 28.782 penderita pada tahun 2012. Berdasarkan data Riset Kesehatan Dasar (RISKESDAS) tahun 2013, prevalensi penyakit ginjal kronik Propinsi DKI Jakarta menduduki urutan ketiga sebesar 0,3\% setelah Sulawesi Tengah 0,5\%, diikuti oleh Aceh, Gorontalo, dan Sulawesi Utara masing-masing 0,4\%, (Riskesdas, 2013).

Pasien penyakit ginjal kronik yang menjalani terapi hemodialisa memiliki banyak masalah, salah satu diantaranya adalah bersihan urea yang kurang maksimal yang ditandai dengan rebound urea yang masih tertinggal didalam darah. Untuk mengoptimalkannya dilakukan pemantauan terhadap adekuasi hemodialisa. Adekuasi hemodialisa merupakan pemantauan yang sangat penting terhadap kecukupan dosis pemberian hemodialisa pada pasien penyakit ginjal kronik. Fenomena yang peneliti dapatkan terhadap evaluasi keefektifan tindakan hemodialisa melalui pemantauan terhadap adekuasi hemodialisa di RSIJ Sukapura didapatkan data bahwa evaluasi nilai adekuasi hemodialisa belum dilakukan dengan baik. Hal ini diketahui jugadari hasil 
wawancara yang peneliti lakukan dengan perawat ruang hemodialisa di RSIJ Sukapura mengatakan perhitungan URR di unit hemodialisa di RSIJ Sukapura dilakukan untuk yang pertama kali saat pasien mendapatkan terapi hemodialisa, dan pemeriksaan terhadap nilai ureum pasien hemodialisa dilakukan 2 minggu sekali atau situasional jika pasien menunjukkan tanda uremia.

Belum terpenuhinya adekuasi hemodialisa secara optimal pada pasien penyakit ginjal kronik dengan hemodialisa dapat terjadi karena ketidakefektifan pembuangan urea dalam darah pada saat proses hemodialisa terjadi karena perpindahan ureum dan zat toksin dari darah ke mesin yang tidak adekuat sehingga rebound urea yang tertinggal masih tinggi di dalam darah. Bersihan urea yang kurang optimal ini juga disebabkan oleh rendahnya aliran darah yang menuju mesin dialiser meskipun sudah diatur berdasarkan peresepan atau dosis yang ditetapkan yang dapat disebabkan karena pompa jantung yang kurang adekuat sehingga ejeksi darah ke mesin hemodialisa berkurang yang dapat juga berpengaruh terhadap proses ultrafiltrasi.

Salah satu upaya untuk meningkatkan bersihan urea yaitu dengan meningkatkan $\mathrm{Qb}$ atau aliran darah yang menuju pada mesin dialiser dalam proses hemodialisa yaitu dengan melakukan exercise intradialisis (latihan fisik). Tujuan exercise intadialisis adalah untuk mengoptimalkan luas permukaan kapiler pembuluh darah untuk membuka lebih besar sehingga mampu meningkatkan pengeluaran ureum, kreatinin dan zat toksin lainnya dari dalam tubuh (Orti, 2010).

Exercise intradialisis merupakan pergerakan terencana, terstruktur yang dihasilkan dari kontraksi otot yang dilakukan untuk memperbaiki atau memelihara satu atau lebih aspek kebugaran (Orti, 2010). Nasution (2010)mengatakan pada exercise yang reguler dan teratur, glikogen akan dipecah menjadi glukosa yang kemudian bereaksi dengan oksigen yang kemudian menghasilkan karbondioksida dan air serta melepaskan energi. Terdapat tiga jenis resistensi exercise intradialisis pada pasien penyakit gagal ginjal kronik yaitu flexibility exercise, strengthening exercise dan cardiovasculer exercise, (Nasution, 2010).

Exersice intradialisis pada tahap flesibility exercise berfungsi membantu persendian bekerja dengan halus dan membantu untuk menekuk sendi, menyentuh dan memindahkan benda lebih mudah. Fleksibility exesice adalah latihan yang menggunakan peregangan otot halus dan gerakan yang lambat. Strengthening exersice adalah latihan otot yang lebih kuat. Latihan kekuatan ini menggunakan tahanan (beban, elastic, bands dan beban pasien sendiri) yang bertujuan membuat otot lebih kuat. Cardivasculer exersice membuat kerja jantung, paru dan sirkulasi tubuh untuk bekerja lebih efisien. Cardiovaskuler exersice menggunakan tahanan, irama, gerakan tangan atau gerangan kaki.

Soliman (2015) dalam penelitiannya tentang pengaruh latihan intradialisis pada kelelahan, tingkat elektrolit, dan tekanan darah pada pasien hemodialisa menyatakan bahwa setelah 8 minggu dilakukan latihan fisik intradialisis Range Of Motion (ROM) selama 15 menit/hari, didapatkan hasil penurunan yang signifikan terlihat pada tingkat kelelahan, fosfat serum dan kalium, kalsium, urea, kreatinin, dan sedikit peningkatan kadar hemoglobin, tekanan darah sistolik dan diastolik berubah secara signifikan pada kelompok intervensi $(P<0,05)$.

Berdasarkan hasil wawancara yang peneliti lakukan dengan perawat ruang hemodialisa RSIJ Sukapura didapatkan data bahwa tidak ada intervensi lain yang dilakukan perawat ruang hemodialisa terhadap masalah yang berkaitan dengan adekuasi hemodialisa dan belum ada penelitian sebelumnya terkait dengan adekuasi hemodialis 
pada pasien penyakit ginjal kronik yang menjalani terapi hemodialisa di ruang hemodialisa RSIJ Sukapura.

\section{METODE PENELITIAN}

Penelitian ini merupakan penelitian kuantitatif dengan menggunakan metode penelitian eksperimen dimana dalam peneliltian ini penelilti akan menguji hubungan sebab akibat dariexercise intradialisis barbell dan Range Of Motion (ROM) terhadap adekuasi hemodialisis pada pasien penyakit ginjal kronik yang menjalani hemodialisa. Disini peneliti membagi subyek menjadi kelompok-kelompok dengan variabel penelitian yang akan diteliti. Rancangan penelitian ini menggunakan desain denganNon probalitas (non bability samples) pre dan post test two groups without control design. Penelitian iniakan melakukan suatu intervensi pada sekelompok subjek tanpa pembanding dengan kelompok kontrol, efektifitas perlakuan dinilai dengan cara membandingkan nilai pretest dan posttest pada masing-masing kelompok (Dharma, 2011).

Populasi dalam penelitian ini adalah semua pasien penyakit ginjal kronik yang menjalani hemodialisa di RSIJ Sukapura berdasarkan jadwal kunjungan hemodialisa dua kali seminggu sebanyak 114 responden. Sampel dalam penelitian ini adalah pasien yang menjalani hemodialisa baik laki-laki maupun perempuan di RSIJ Sukapura pada saat dilakukan penelitian yang berjumlah 32 responden dibagi menjadi 2 kelompok dan setiap kelompok ditentukan dengan teknik purposive sampling.

Analisis dengan menggunakan SPSS 24 digunakan untuk menganalisis variabel yang bersifat kategorik dan variabel numerik, sedangkan untuk analisis bivariat menggunakan uji T dependen (Paired T Test).

\section{HASIL PENELITIAN \\ Karakteristik responden}

Tabel. 1

Distribusi Frekuensi Berdasarkan Karakteristik Responden pada Pasien Penyakit Ginjal Kronik

\begin{tabular}{clcccc}
\hline \multirow{2}{*}{ Karakteristik } & \multirow{2}{*}{ Kategori } & \multicolumn{2}{c}{ Kelompok Intervensi I } & \multicolumn{2}{c}{ Kelompok Intervensi II } \\
\cline { 3 - 6 } & & $\mathrm{N}$ & $\%$ & $\mathrm{~N}$ & $\%$ \\
\multirow{2}{*}{ Jenis Kelamin } & Laki-laki & 11 & 61,1 & 9 & 50,0 \\
& Perempuan & 7 & 38,9 & 9 & 50,0 \\
\hline
\end{tabular}

Berdasarkan data di atas, jumlah responden untuk semua kelompok intervensi sebanyak 36 responden dengan 18 responden pada masing-masing kelompok intervensi. Pada intervensi 1 jumlah responden yang berjenis kelamin laki-laki sebanyak 11 orang atau $62,1 \%$ dan responden yang berjenis kelamin perempuan sebanyak 7 orang atau $38,9 \%$. Sedangkan pada intervensi II responden yang berjenis kelamin laki-laki sebanyak 9 orang atau 50,0 \% dan responden yang berjenis kelamin perempuan sebanyak 9 orang atau 50,0 \%. Hal ini dapat disimpulkan bahwa responden terbanyak dalam penelitian ini adalah responden yang berjenis kelamin laki-laki. 
Tabel. 2

Rata-Rata Nilai Adekuasi Hemodialisa Sebelum dan Sesudah Dilakukan Intervensi Barbell pada Kelompok Intervensi 1 pada Pasien Penyakit Ginjal Kronik

\begin{tabular}{clcccc}
\hline Variabel & Pengukuran & Mean & SD & Min-Mak & 95\% CI \\
\hline Adekuasi Hemodialisa & Sebelum & 1,72 & 0,3455 & $1,8-2,8$ & $2,034-2,377$ \\
& Sesudah & 1,33 & 0,2431 & $1,6-2,4$ & $1,724-1,965$ \\
\hline
\end{tabular}

Berdasarkan data diatas, diketahui nilai rata-rata adekuasi pada kelompok intervensi I (burbell) sebelum dan sesudah diberikan intervensi antara lain: untuk nilai adekuasi hemodialisa sebelum dilakukan intervensi adalah 1,72, dengan standard deviasi 0,3455 , nilai min-maks 1,8-2,8 dan tingkat kepercayaan 95\% adalah 2,0342,377. Sedangkan untuk nilai adekuasi sesudah dilakukan intervensi adalah 1,33 standard deviasi 0,2431, nilai min-maks 1,6-2,4 dan tingkat kepercayaan 95\% adalah 1,724-1,965. Ini berarti intervensi barbell berpengaruh terhadap adekuasi hemodialisa.

Tabel. 3

Rata-rata Nilai Adekuasi Hemodialisa Sebelum dan Sesudah Dilakukan Intervensi ROM pada Kelompok Intervensi II (ROM) Pada Pasien Gagal Ginjal Kronik

\begin{tabular}{llcccc}
\hline \multicolumn{1}{c}{ Variabel } & Pengukuran & Mean & SD & Min-Maks & 95\% C1 \\
\hline Adekuasi & Sebelum & 1,83 & 0,2890 & $1,8-2,8$ & $2,056-2,344$ \\
Hemodialisa & Sesudah & 1,67 & 0,2567 & $1,6-2,6$ & $1,872-2,128$ \\
\hline
\end{tabular}

Berdasarkan data diatas, diketahui nilai rata-rata adekuasi pada kelompok ROM sebelum dan sesudah diberikan intervensi II (ROM) antara lain: untuk nilai adekuasi sebelum dilakukan intervensi adalah 1,83 dengan standard deviasi 0,2890. Sedangkan untuk nilai adekuasi sesudah dilakukan intervensi adalah 1,67 dengan standard deviasi 0,2567. Ini dapat disimpulkan bahwa intervensi ROM berpengaruh terhadap adekuasi hemodialisa.

Tabel. 4

Perbedaan Rata-rata Nilai Adekuasi Hemodialisa Sebelum dan Sesudah Dilakukan Intervensi Barbell pada Pelompok Intervensi I pada Pasien Penyakit Ginjal Kronik

\begin{tabular}{lccccccc}
\hline \multicolumn{1}{c}{ Variabel } & Kelompok & Mean & $S D$ & $S E$ & CI 95\% & P Value & $\mathrm{n}$ \\
\hline Adekuasi Hemodialisa & Sebelum & 1,72 & 0,461 & 0,109 & $2,034-2,377$ & 0,004 & \\
\cline { 2 - 6 } Intervensi I & Sesudah & 1,33 & 0,458 & 0,114 & $1,724-1,965$ & & \\
\hline $\begin{array}{l}\text { Selisih Adekuasi } \\
\text { Hemodialisa Intervensi }\end{array}$ & $\begin{array}{c}\text { Sebelum dan } \\
\text { sesudah }\end{array}$ & 0,39 & 0,003 & $-0,005$ & 0,31 dan 0,412 & & 18 \\
\hline
\end{tabular}

Berdasarkan data diatas nilai rata-rata adekuasi hemodialisa sebelum diberikan intervensi yaitu mean 1,72 dengan standar deviasi 0,461 sedangkan nilai rata-rata sesudah diberikan intervensi yaitu mean 1,33 dengan standar deviasi 0,458. Hasi Uji T (paired samples test) pada adekuasi hemodialisa diperoleh nilai $p$ value 0,004 yang artinya adalah bahwa ada perbedaan yang signifikan pada adekuasi hemodialisa sebelum dan sesudah diberikan intervensi barbell, hal ini menunjukkan $p$ value $<\dot{\alpha}$ $(0,05)$. 
Tabel. 5

Perbedaan Rata-rata Nilai Adekuasi Hemodialisa Sebelum dan Sesudah Intervensi ROM pada Kelompok Intervensi II (ROM) pada Pasien Penyakit Ginjal Kronik

\begin{tabular}{llcccccc}
\hline Variabel & Kelom-pok & Mean & SD & SE & CI 95\% & P Value & $\mathrm{n}$ \\
\hline Adekuasi Hemodialisa & Sebelum & 1,83 & 0,383 & 0,090 & $2,056-2,344$ & & \\
Intervensi I & Sesudah & 1,67 & 0,485 & 0,114 & $1,872-2,128$ & & \\
Selisish Adekuasi & Sebelum & 0,16 & $-0,102$ & $-0,024$ & $0,184 \& 0,216$ & 0,083 & 18 \\
$\begin{array}{l}\text { Hemodialisa Intervensi I dan } \\
\text { sesudah }\end{array}$ & & & & & & \\
\hline
\end{tabular}

Berdasarkan data di atas nilai rata-rata adekuasi hemodialisa sebelum diberikan intervensi yaitu 1,83 dengan standar deviasi 0,383, standar eror 0,90. Sedangkan nilai rata-rata setelah diberikan intervensi yaitu 1,67 dengan standar deviasi 0,485 , standar eror 0,114 . Hasil uji $T$ (paired samples test) pada adekuasi hemodialisa diperoleh nilai $p$ value 0,083 yang artinya adalah bahwa tidak ada perbedaan yang signifikan pada adekuasi hemodialisa sebelum dan sesudah diberikan intervensi ROM, hal ini menunjukkan $p$ value $>\dot{\alpha}(0,05)$.

Tabel. 6

Perbedaan Efektifitas Nilai Adekuasi Hemodialisa Sesudah Diberikan Intervensi Barbell pada Kelompok Intervensi I (barbell) dan Intervensi ROM pada Kelompok Intervensi II (ROM)

\begin{tabular}{lcccccc}
\hline \multicolumn{1}{c}{ Variabel } & Kelompok & Mean & SD & SE & CI 95\% & P value \\
\hline Selisih & Intervensi I (Barbell) & 0,39 & 0,003 & $-0,005$ & $0,31-0,412$ & 0,047 \\
Adekuasi & Intervensi II (ROM) & 0,16 & $-0,102$ & $-0,024$ & $0,184-0,216$ & \\
Hemodialisa & & & & & &
\end{tabular}

Berdasarkan data di atas, menunjukkan bahwa selisish rata-rata nilai adekuasi hemodialisa pada kelompok intervensi I (barbell) adalah 0,39 dengan standar deviasi 0,003, standar eror -0,005, dan tingkat kepercayaan CI 95\% 0,31-0,412. Sedangkan selisish nilai adekuasi pada kelompok intervensi II (ROM) adalah 0,16 dengan standar deviasi -0,102, standar eror -0,024, dan tingkat kepercayaan CI 95\% 0,184-0,216. Hal ini menunjukkan bahwa intervensi barbell lebih efektif dibandingkan dengan intervensi ROM dimana selisih rata-rata nilai adekuasi hemodialisa pada intervensi barbell lebih besar yakni 0,39, jika dibandingkan dengan selisih rata-rata nilai adekuasi pada intervensi ROM yakni 0,16 . Hasil uji statistik menunjukkan $p$ value $0,047(>0,05)$. Hal ini dapat disimpulkan bahwa tidak ada perbedaan nilai yang bermakna pada adekuasi hemodialisa antara kelompok intervensi I dan intervensi II setelah intervensi I dan II.

\section{PEMBAHASAN}

\section{Karakteristik Responden}

Hasil analisis univariat variabel jenis kelamin menunjukkan bahwa sebagian besar responden pada kedua kelompok intervensi adalah berjenis kelamin laki-laki yakni jumlah responden laki-laki pada intervensi I sebanyak 11 orang atau 62,1\% dan jumlah responden perempuan pada intervensi I sebanyak 7 orang atau 38,9\%. Sedangkan jumlah responden yang berjenis kelamin laki-laki pada intervensi II sebanyak 9 orang atau 50,0 \% dan responden yang berjenis kelamin perempuan sebanyak 9 orang atau $50,0 \%$. Oleh sebab itu, dapat disimpulkan bahwa responden terbanyak dalam penelitian 
ini adalah responden yang berjenis kelamin laki-laki.

Penyakit ginjal kronik merupakan istilah umum yang menggambarkan kerusakan ginjal atau penurunan laju filtrasi glomelurus (GFR) yang berlangsung selama 3 bulan atau lebih. Penyakit ginjal kronik diasosiasikan dengan kualitas hidup, peningkatan perawatan kesehatan dan kematian dini (Brunner, Suddarth's,2014).

Terapi hemodialisa melibatkan penggunaan ginjal buatan untuk membuang produk limbah dan kelebihan air antara kompartemen darah dengan kompartemen dialiser melalui membran semipermeabel pada pasien dengan gagal ginjal kronik (Roesli, 2013).

Jenis kelamin merupakan identitas seksual yang dimiliki seseorang sejak lahir. Jenis kelamin dapat mempengaruhi proses hemodialisa dikarenakan oleh perhitungan nilai volume cairan tubuh dalam liter yang ditarik dalam proses hemodialisa pada lakilaki 65\% dan wanita 55\% BB (Berat Badan) (Penefri, 2013).

Sebagian besar responden yang melakukan intervensi baik barbell maupun ROM adalah berjenis kelamin laki-laki dimana pengunjung atau pasien hemodialisa terbanyak adalah pasien yang berjenis kelamin laki-laki. Hal ini dipengaruhi oleh kemampuan responden dalam melakukan gerakan menggunakan barbell dengan berat $2 \mathrm{Kg}$ sebanyak 8 kali hitungan dengan 2 kali pengulangan. Sebagian besar responden yang mampu melakukan gerakan tersebut adalah laki-laki. Hal ini bisa dikarenakan oleh ukuran dan kekuatan otot dimana otot laki-laki lebih besar dan lebih kuat jika dibandingkan dengan otot perempuan sehingga mempengaruhi dalam kemampuan melakukan gerakan tersebut (mengangkat barbell). Selain itu juga, berdasarkan fenomena yang terjadi di RSIJ Sukapura, sebagian besar pasien yang menjalani terapi hemodialisa adalah pasien yang berjenis kelamin perempuan. Berdasarkan hasil wawancara yang didapat, pasien yang berjenis kelamin laki-laki memiliki riwayat kebiasaan hidup yang buruk dimana sebagian besar dari mereka mengaku sering minum minuman bersoda, minuman penambah energi (ekstra jos, jamu-jamu tradisional), dan kurang minum air mineral. Disamping itu juga, terapi hemodialisa berkaitan dengan pembuluh darah yang mengalirkan darah ke mesin hemodialisa. Oleh karena itu, jenis kelamin sangat mempengaruhi proses hemodialisa. Pembuluh darah laki-laki lebih besar jika dibandingkan dengan pembuluh darah perempuan. Hal ini dapat berpengaruh pada proses aliran darah ke mesin dialiser. Responden yang berjenis kelamin laki-laki mengalami pembersihan urea lebih banyak sehingga mempengaruhi adekuasi hemodialisa.

Penelitian yang sejalan dengan penelitian ini adalah Musavian (2015) dalam penelitiannya tentang perbandingan efek aktif dan pasif khasiat latihan intradialisis mengayuh selama dialisis pada elektrolit, hemoglobin, hematokrit, tekanan darah, dan kualitas kesehatan pada pasien hemodialisa. Metode penelitian yang digunakan adalah randomisasi dengan besar sampel sebanyak 40 responden dengan hasil antara lain : sebagian besar responden berjenis kelamin laki-laki yaitu 28 responden dan 10 responden lainnya berjenis kelamin perempuan

Penelitian lain yang dilakukan oleh Hartanti (2013) tentang pengaruh exersice intradialisis terhadap adekuasi hemodialisis pada pasien penyakit ginjal terminal. metode penelitian yang digunakan peneliti adalah randomisasi pada 2 kelompok yakni kelompok intervensi dan kelompok kontrol dengan jumlah sampel sebanyak 38 responden. Pada penelitian ini didapatkan hasil antara lain: berdasarkan jenis kelamin sebagian besar responden berjenis kelamin laki-laki, yaitu sebanyak 12 orang pada kelompok kontrol dan sebanyak 13 orang pada kelompok intervensi. 


\section{Rata-Rata Nilai Adekuasi Sebelum dan Sesudah Dilakukan Intervensi Barbell pada Kelompok Intervensi I}

Nilai rata-rata adekuasi hemodialisa pada pengukuran awal pada hari pertama sebelum dilakukan intervensi pada kelompok barbell adalah 1,72 dengan standar deviasi 0,3455 dan pada pengukuran kedua yang dilakukan pada hari pertemuan ke sepuluh didapatkan penurunan nilai rata-rata adekuasi hemodialisa menjadi 1,33 dengan standar deviasi 0,2431 diperoleh $p$ value $=0,004$ yang artinya bahwa ada perbedaan yang signifikan pada nilai adekuasi hemodialisa sebelum dan sesudah diberikan intervensi barbell. Hal ini menunjukkan $p$ value $<0,05$.

Pemberian intervensi barbell yang dapat berpengaruh pada adekuasi hemodialisa pada pasien penyakit ginjal kronik di ruang hemodialisa dikaitkan dengan peningkatan nilai $\mathrm{Qb}$ atau aliran darah yang menuju pada mesin dialiser dalam proses hemodialisa< 400 Penefri 2013.

Hasil penelitian pada kelompok ini menunjukkan terjadi penurunan pada adekuasi hemodialisa sebelum dan sesudah diberikan intervensi barbell. Pada penelitian ini, intervensi barbell dengan berat $2 \mathrm{Kg}$ pada ekstremitas atas dan 0,5 untuk ekstremitas bawah, dilakukan sebanyak dua kali dalam seminggu selama 4 minggu dengan masingmasing waktu 20-30 menit yang terdiri dari 11 langkah melalui 3 tahapan yaitu latihan pemanasan selama \pm 5 menit, latihan inti selama $\pm 5-15$, dan latihan pendinginan selama \pm 5-10 menit. Latihan dilakukan sebanyak 8 kali hitungan dengan 2 kali pengulangan setiap gerakan. Latihan akan memperlihatkan hasil tergantung dari frekuensi, waktu serta pengolahan adekuasi hemodialisa. Gerakan dengan menggunakan beban sangat berpengaruh dalam keefektifan nilai adekuasi, dimana dapat merangsang saraf simpatik untuk mengoptimalkan luas permukaan kapiler pembuluh darah sehingga bisa membuka lebih besar, kerja jantung semakin meningkat (dari lemah menjadi kuat, dari peredaran darah tidak lancar menjadi lancar), dan membuat darah yang banyak mengandung ureum dan zat toksin mengalir lebih banyak ke mesin dialiser untuk dibersihkan. Dengan begitu ureum dalam tubuh pasien hemodialisa bisa cepat berkurang. Hal ini berpengaruh pada nilai adekuasi hemodialisa.

Hasil penelitian ini sejalan dengan hasil penelitian Hartanti (2013) penelitian tentang adekuasi hemodialisis pada pasien gagal ginjal terminal yang menjalani hemodialisis dengan jumlah responden sebanyak 44 orang, hasil penelitian menunjukan intervensi barbell yang dilakukan sebanyak 8 kali intervensi, di ruang hemodialisa dengan intervensi sebanyak 3 kali seminggu selama kurang lebih 20-30 menit per latihan terdapat hubungan yang signifikan antara intervensi barbell dengan adekuasi hemodialisis pada pasien hemodialisis dengan nilai $p$ value 0,04 ( $p$ value $<0,05$ ).

\section{Rata-Rata Nilai Adekuasi Hemodialisa Sebelum dan Sesudah Dilakukan Intervensi ROM pada Kelompok Intervensi II}

Untuk nilai rata-rata adekuasi hemodialisa pada pengukuran awal pada kelompok ROM yang dilakukan pada hari pertama sebelum dilakukan intervensi diketahui nilai rata-rata adekuasi hemodialisa adalah 1,83 dengan standar deviasi 0,2890 dan pada pengukuran kedua yang dilakukan pada hari ke sepuluh didapatkan terjadinya penurunan nilai rata-rata adekuasi hemodialisa yakni 1,67 dengan standar deviasi 0,2567 diperoleh $p$ value $=0,83$ yang artinya tidak ada perbedaan yang signifikan pada adekuasi hemodialisa sebelum dan sesudah diberikan intervensi ROM. Hal ini menunjukkan $p$ value $>0,05$. 
Pemberian intervensi ROM yang dapat berpengaruh pada adekuasi hemodialisa pada pasien gagal ginjal kronik di ruang hemodialisa dikaitkan dengan peningkatan nilai Qb atau aliran darah yang menuju pada mesin dialiser dalam proses hemodialisa, dimana tujuan dari exercise intradialisis ROM bertujuan untuk mengoptimalkan luas permukaan kapiler pembuluh darah untuk membuka lebih besar sehingga mampu meningkatkan pengeluaran ureum, kreatinin dan zat troksin lainnya dari dalam tubuh.Dengan demikian ureum dalam darah pasien hemodialisa masih banyak, hal ini dapat berpengaruh pada adekuasi hemodilisa.

Hasil penelitian pada kelompok ini menunjukkan terjadi penurunan pada adekuasi hemodialisa sebelum dan sesudah diberikan intervensi. Pada penelitian ini dengan intervensi ROM dilakukan sebanyak dua kali dalam seminggu selama 4 minggu dengan masing-masing waktu 20-30 menit yang terdiri dari 16 langkah melalui 3 tahapan yaitu latihan pemenasan selama \pm 5 menit, latihan inti selama $\pm 5-15$, dan latihan pendinginan selama \pm 5-10 menit. Latihan ini dilakukan dengan 8 kali hitungan dengan 2 kali pengulangan setiap gerakan. Exercise akan memperlihatkan hasil tergantung dari frekuensi, waktu serta pengolahan adekuasi hemodialisa. Perubahan nilai adekuasi pada intervensi ROM sangat sedikit jika dibandingkan dengan intervensi barbell. Hal ini dikarenakan pada intervensi ROM tidak menggunakan beban sehingga sangat sedikit pengaruh terhadap saraf simpatik untuk membuka lebih besar kapiler darah sehingga darah yang banyak mengandung ureum dan zat toksin lebih sedikit menuju mesin dialiser untuk dibersihkan. Dengan begitu kadar ureum dalam darah pada pasien hemodialisa yang melakukan intervensi ROM masih banyak jika dibandingkan dengan darah pada pasien hemodialisa yang melakukan intervensi barbell.

Penelitian ini sejalan dengan hasil penelitian Soliman (2015) yang menunjukan intervensi ROM yang dilakukan selama 8 minggu, di ruang hemodialisa dengan intervensi sebanyak 3 kali seminggu selama kurang lebih 10-15 menit per latihan terdapat hubungan yang signifikan antara intervensi ROM dengan adekuasi hemodialisis pada pasien hemodialisis dengan $p$ value 0,02 ( $p$ value $<0,05)$.

\section{Perbedaan Efektifitas Nilai Adekuasi Hemodialisa Sebelum dan Sesudah Diberikan Intervensi Barbell pada Kelompok Intervensi I dan intervensi ROM pada Kelompok Intervensi II}

Hasil perbedaan efektifitas menunjukkan bahwa selisih rata-rata nilai adekuasi hemodialisa pada kelompok intervensi I adalah 0,39 dengan standar deviasi 0,003, standar eror -0,005, dan tingkat kepercayaan CI 95\% 0,31-0,412. Sedangkan selisish rata-rata nilai adekuasi hemodialisa pada kelompok intervensi II adalah 0,16 dengan standar deviasi -0,102, standar eror -0,024, dan tingkat kepercayaan CI 95\% 0,1840,216 . Berdasarkan hasil nilai perbedaan efektifitas rata-rata nilai adekuasi hemodialisa tersebut menunjukkan bahwa intervensi barbell lebih efektif dibandingkan dengan intervensi ROM dimana selisih rata-rata nilai adekuasi hemodialisa pada intervensi barbelllebih besar yakni 0,39, jika dibandingkan dengan selisih rata-rata nilai adekuasi pada intervensi ROM yakni 0,16 . Hasil uji statistik menunjukkan nilai $p$ value 0,047 $(>0,05)$. Hal ini dapat disimpulkan bahwa tidak ada perbedaan nilai yang bermakna pada adekuasi hemodialisa antara kelompok intervensi I (barbell) dan intervensi II (ROM) setelah intervensi I barbell dan II (ROM).

Pemberian intervensi barbell dan ROM yang dapat berpengaruh pada adekuasi hemodialisa pada pasien penyakit ginjal kronik di ruang hemodialisa dikaitkan dengan peningkatan nilai $\mathrm{Qb}$ atau aliran darah yang menuju pada mesin dialiser dalam proses 
hemodialisa< 400. Tujuan dari exercise intradialisis untuk mengoptimalkan luas permukaan kapiler pembuluh darah untuk membuka lebih besar sehingga mampu meningkatkan pengeluaran ureum, kreatinin dan zat troksin lainnya dari dalam tubuh. Dengan demikian ureum dalam darah pasien hemodialisa masih banyak, sehingga berpengaruh pada keefektifan adekuasi hemodilisa.

Hasil penelitian baik pada kelompok barbell maupun pada kelompok ROM tergantung dari intensitas, frekuensi, dan waktu pelaksanaan intervensi. Semakin berat intervensi yang dilakukan maka semakin besar peluang terangsangnya saraf simpatik untuk membuka lebih besar permukaan kapiler pembuluh darah sehingga darah yang banyak mengandung ureum dan zat toksin lainnya lebih banyak mengalir ke mesin dialiser untuk dibersihakn. Maka semakin besar pula ureum dan zat toksin yang dibuang saat proses hemodialisa. Hal ini bisa dilihat antara kelompok intervensi I dan kelompok intervensi II, dimana dari kedua intervensi tersebut menunjukkan bahwa intervensi barbell lebih berat jika dibandingkan dengan intervensi ROM. Intervensi barbell menggunakan beban dengan berat $2 \mathrm{Kg}$ pada ekstremitas atas dan $0,5 \mathrm{Kg}$ pada ekstremitas bawah, sedangkan pada intervensi ROM hanya melakukan gerakan pada ekstremitas atas dan bawah tanpa menggunakan beban. Oleh karena itu, efek yang besar pada perubahan nilai adekuasi hemodialisa terlihat pada kelompok intervensi I sehingga dapat disimpulkan bahwa intervensi barbell pada kelompok intervensi I lebih efektif jika dibandingkan dengan intervensi ROM pada kelompok intervensiII.

\section{SIMPULAN}

Karakteristik responden pada penelitian ini meliputi jenis kelamin yang dapat mempengaruhi adekuasi hemodialisa. Hasil penelitian menunjukan bahwa jenis kelamin responden pada penelitian ini sebagian besar berjenis kelamin laki-laki, dimana pada kelompok burbell responden yang berjenis kelamin laki-laki sebanyak 11 orang atau $61,1 \%$ sedangkan responden yang berjenis kelamin perempuan sebanyak 7 orang atau 38,9 \%. Pada kelompok ROM, responden yang berjenis kelamin laki-laki sebanyak 9 orang atau 50,0 \% sedangkan responden yang berjenis kelamin perempuan sebanyak 9 orang atau \% 50,0 dengan jumlah responden seluruhnya sebanyak 38 orang atau $100 \%$.

Rata-rata nilai adekuasi sebelum dan sesudah dilakukan intervensi barbell pada kelompok intervensi I (barbell) adalah 1,72 dengan standar deviasi 0,461 dan pada pengukuran kedua yang dilakukan pada hari ke sepuluh didapatkan penurunan nilai rata-rata adekuasi hemodialisa menjadi 1,33 dengan standar deviasi 0,485 diperoleh nilai $p$ value $=0,004$ yang artinya bahwa ada perbedaan yang signifikan pada nilai adekuasi hemodialisa sebelum dan sesudah diberikan intervensi burbell.

Rata-rata nilai adekuasi hemodialisa sebelum dan sesudah dilakukan intervensi ROM pada kelompok intervensi II (ROM) adalah 1,83 dengan standar deviasi 0,2890 dan pada pengukuran kedua yang dilakukan pada hari ke sepuluh didapatkan terjadinya penurunan nilai rata-rata adekuasi hemodialisa yakni 1,67 dengan standar deviasi 0,2567 diperoleh $p$ value lebih kecil yaitu $0,004(<0,05)$, hal ini menunjukkan tidak ada perbedaan yang bermakna terhadap adekuasi hemodialisa dimana $p$ value lebih besar yaitu $0,083(>0,05)$. 


\section{SARAN}

1. Pelayanan Keperawatan

Berdasarkan hasil penelitian ini, sangat disarankan kepada pelayanan keperawatan dapat melakukan pemberian intervensi latihan fisik menggunakan burbell selama hemodialisa sebagai intervensi keperawatan mandiri yang dapat diajarkan perawat kepada pasien ginjal kronik yang sedang menjalani hemodialisa di ruang hemodialisa.

2. Pendidikan Keperawatan

Hasil penelitian ini diharapan dapat menjadi bahan pembelajaran dan referensi bagi kalangan yang akan melakukan pnelitian lebih lanjut dengan topik yang berhubungan dengan judul ini.

3. Penelitian Selanjutnya

Penelitian ini bersifat aplikatif, sehingga dapat disarankan untuk dikembangkan lagi untuk memperkaya ilmu pengetahuan keperawatan terutama intervensi mandiri. Diharapkan pada penelitiasn selanjutnya melakukan pengecekan kemampuan dengan beban burbell sesuai dengan kemampuan pasien yang diletakkan di kaki di mana pada variabel ini belum dilakukan pengecekan kemampuan pada kaki pasien.

\section{DAFTAR PUSTAKA}

Brunner \& Suddarth's. (2014). Text Book Of Medical-Surgical Nursing. Wolters Kluwer: Lippincott Williams \& Wilkins

Dharma, K. K. (2011). Metodologi Penelitian Keperawatan Panduan Melaksanakan dan Menerapkan Hasil Penelitian. Jakarta: Trans Info Media

Hartanti, A. D. (2013). Pengaruh Exercise Intradialisis terhadap Adekuasi Hemodialisis Pasien Penyakit Ginjal Terminal. Naskah Tesis. Diperoleh dari https://www.unimus.ac..id/index.php/psn12012020/article Diunduh pada tanggal 20 Februari 2018

Musavian, A. S., \& Alavi, N. M. (2015). Comparing the Effects of Active and Passive Intradialytic Pedaling Exercise on Dialysis Efficacy, Electrolytes, Hemoglobin, Hematocrit, Blood Plessure and Health-Related Quality of Life. Jounal of Nursing Education and Pratice, 4(1). Diperoleh dari www.sciedu.ca/jnep. Diunduh pada tanggal 19 Maret 2018

Nasution. (2010). Perawatan pada Pasien Penyakit Ginjal yang Menjalani Hemodialisa Secara Komprehensif. Jakarta: PPGI

Orti, E. S. \& Johnansen, K. L. (2010). Exercise in Hemodialysis Patients : Literature Systematic Review. Nefrologia, 30(2), 236-246. Diperoleh dari http://www.revistanefrologia.com diunduh pada tanggal 19 Maret 2018

Pernefri (Perhimpunan Nefrologia Indonesia). (2013). Konsesus Dialisis. Naskah tidak dipublikasikan

Riskesdas. (2013). Riset Kesehatan Dasar. Diambil dari Badan Penelitian dan Pengembangan Kesehatan Kementrian Kesehatan RI. Diperoleh dari www.depkes.go.id/resources/download/general/Hasil\%Riskesdas\%2020 13. Pdf. Diunduh pada tanggal 18 Maret 2018

Roesli, M. A. (2013). Diagnosis dan Pengolaan Gangguan Ginjal Kronik. Jakarta; Puspa Swara 
Sastroasmoro S. S \& Ismail. (2011). Dasar-Dasar Metodologi Penelitian Klinis edisi ke-4. Jakarta ; CV Sagung Seto

Soliman, H. M. (2015). Effect of Intradialytic Exercise on Fatique, Electrolyte, Level and Blood Pressure in Hemodialisis Pasient: A Randomozed Controlled Trial. Journal of Nursing Education and Practice, 4(1). Diperoleh dari www.sciedu.ca/jnep. Diunduh pada tanggal 19 Maret 2018

USRDS (United States Renal Data System). (2013). 2013 USRDS Annual Data Report, Volume 2, End-Stage Renal Desease. Diperoleh dari : http://www.usrds.org. Diunduh pada tanggal 18 Maret 2018

Yayasan Ginjal Diatrans Indonesia. (2013). Gagal Ginjal Kronik. Diperoleh dari: http://www.yagina.org Diunduh pada tanggal 19 Maret 2018 